\title{
Open safety pin ingestion: A pediatric case: Can it be spontaneously eliminated or not?
}

\author{
Açık uçlu çengelli iğne yutulması: Pediatrik bir vaka: Girişim gerektirmeden çıar mı?
}

Guniz YASOZ, Suat BICER, Safiye ULKU OZER, Yakup SOGUTLU, Rabia ERGELEN, Defne COL

Dedicated to the memory of wonderful person and physician Dr. Suat Bicer

\begin{abstract}
Foreign body ingestion is a common problem in childhood. Sharp objects such as needles, toothpicks or open safety pins can also be ingested.

A 13-month-old-boy was admitted to our pediatric emergency department with the suspicion of safety pin ingestion. The boy was taken to a private hospital and an abdominal X-ray was obtained. The open safety pin was seen in the pylorus and he was referred to a university hospital. When he arrived to our pediatric emergency department, an abdominal X-ray was retaken, and an open safety pin was seen in the first part of the duodenum. The patient was hospitalized for observation. After twenty hours, a control X-ray was taken; the open safety pin was seen in the ascending colon. The child was discharged from hospital, and instructions were given to the family for watching his stool closely. The day after, we called the family and learned that the open safety pin was eliminated spontaneously from stool.

Infants and children with safety pin ingestion can be closely followed clinically without complication and there will be no need for an endoscopy and/or surgery. An open safety pin ingested small child was reported with the aim to draw attention to safety pin ingestion.
\end{abstract}

Keywords: Foreign body ingestion, Open safety pin, Blue bead

Guniz Yasoz (四), Safiye Ülku Özer, Yakup Sogutlu

Department of Child Health and Pediatrics, School of Medicine, Marmara University Hospital, Pendik, Istanbul, Turkey

e-mail:gunizyasoz@yahoo.com

Suat Bicer

Department of Pediatric Emergency Medicine, School of Medicine, Yeditepe University Hospital, Istanbul, Turkey

Defne Col

Department of Child Health and Pediatrics, School of Medicine, Yeditepe University Hospital, Istanbul, Turkey

Rabia Ergelen

Department of Radiology, School of Medicine, Marmara University Hospital, Pendik, Turkey

Submitted / Gönderilme: 05.02.2017

Accepted/Kabul: 30.03 .2017
Öz

Çocukluk çağında yabancı cisim yutulması oldukça sık görülen bir durumdur. Bazen toplu iğne, kürdan ya da ucu açık çengelli iğne gibi keskin yabancı cisimler de yutulmaktadır.

13 aylık erkek bebek, çengelli iğne yutma süphesiyle acil servisimize getirildi. Altı saat önce bebeğin sağ omzundaki iğnenin kaybolduğunun fark edilmesi üzerine götürüldüğ̈ özel bir hastanede çekilen düz batın grafisinde, çengelli iğnenin ucu açık olarak pilorda olduğu görülerek bir üniversite hastanesine yönlendirildi. Pediatrik acil servisimize başvurduğunda tekrarlanan batın grafisinde ucu açık çengelli iğnenin duodenumun ilk kısmına ilerlediği gözlemlendi. Hasta gözlem amacıyla hastaneye yatırıldı. Yirmi saat sonra çekilen kontrol grafisinde çengelli iğnenin çıkan kolonda olduğu izlendi. Bebeğe oral beslenme başlandı ve ailesine dışkı kontrolü yapılması için eğitim verilerek poliklinik kontrolüne çağrıldı. Ertesi gün aileyle yapılan telefon görüşmesinde, ucu açık çengelli iğnenin spontan olarak, dışkıyla atıldığı öğrenildi.

Çengelli iğne yutan bebek ve çocuklar, endoskopi ve/veya cerrahi yapılmadan sadece klinik olarak komplikasyonsuz takip edilebilir. Yazımızda, çengelli iğne gibi keskin yabancı cisim yutulmasına dikkat çekmek amacıyla, spontan olarak dışkıyla atılan açık çengelli iğne yutmuş olan bebek rapor edilmiştir.

Anahtar kelimeler: Yabancı cisim yutulması, Ucu açı çengelli iğne, Nazar boncuğu

\section{Introduction}

Foreign body ingestion is a common problem in childhood $[1,2]$. Most children who swallow a foreign body do not require specialized care since many of the foreign bodies pass through the gastrointestinal tract spontaneously without any intervention [3]. Although mortality or morbidity due to the foreign body is rare, some of the sharp objects can cause serious problems [3]. Sharp objects such as needles, open safety pins, toothpicks, screws, nails, tacks can cause obstruction, perforation, abscess, peritonitis, fistula 
formation, appendicitis, penetration to adjacent organs (liver, bladder, heart, lung), incarcerated umbilical hernia, aortoesophageal fistula, rupture of common carotid artery, hemopericardium, and death [3-12]. Before the use of endoscopic techniques, morbidity rates for the ingestion of sharp objects were $35 \%$ and mortality rates were $26 \%$ [13]. Rapid diagnosis and suitable therapy such as endoscopy decreased the incidence of adverse events [14]. Sharp object ingestion rates are between 11\% - 13\% in Europe and Asia [15-17]. The type of ingested objects depends on the country and cultural factors. For example, blue bead ingestions are most frequently encountered in Turkey. These beads are attached to a safety pin for religious or cultural beliefs and used as a good luck charm [18]. Open safety pin ingestions are also common since the blue beads are attached to infants' and children's clothes with safety pins. When the safety pins are unfastened, they can be swallowed easily and can stick at any location in the gastrointestinal tract, especially in the narrowest parts. The location of the swallowed foreign body on the X-ray is important in determining the treatment options. If the sharp object is in the esophagus, removal is considered mandatory [3]. However, once they are beyond the esophagus, most sharp objects pass without any complication and there is no need for any intervention [19]. Yet, they must be closely observed.

In this case report, a 13-month-old-boy who ingested an open safety pin was presented.

\section{Case Report}

A 13-month-old-boy was admitted to our pediatric emergency department with the suspicion of safety pin ingestion. The family found the blue bead in his bed. It was attached the child's clothes with a safety pin. They could not find the safety pin and thought it was ingested. The boy was taken to a private hospital and an abdominal x-ray was obtained. The open safety pin was seen in the pylorus and he was referred to a university hospital. When he arrived to our pediatric emergency department, an abdominal x-ray was retaken and he was referred to pediatric gastroenterology. The open safety pin was seen in the first part of the duodenum (Figure 1). The pediatric gastroenterologist decided to hospitalize the patient to follow up closely and observe him with nil per oral. After twenty hours, a control x-ray was taken; the open safety pin was seen in the ascending colon (Figure 2). The child was discharged from hospital, and instructions were given to the family to

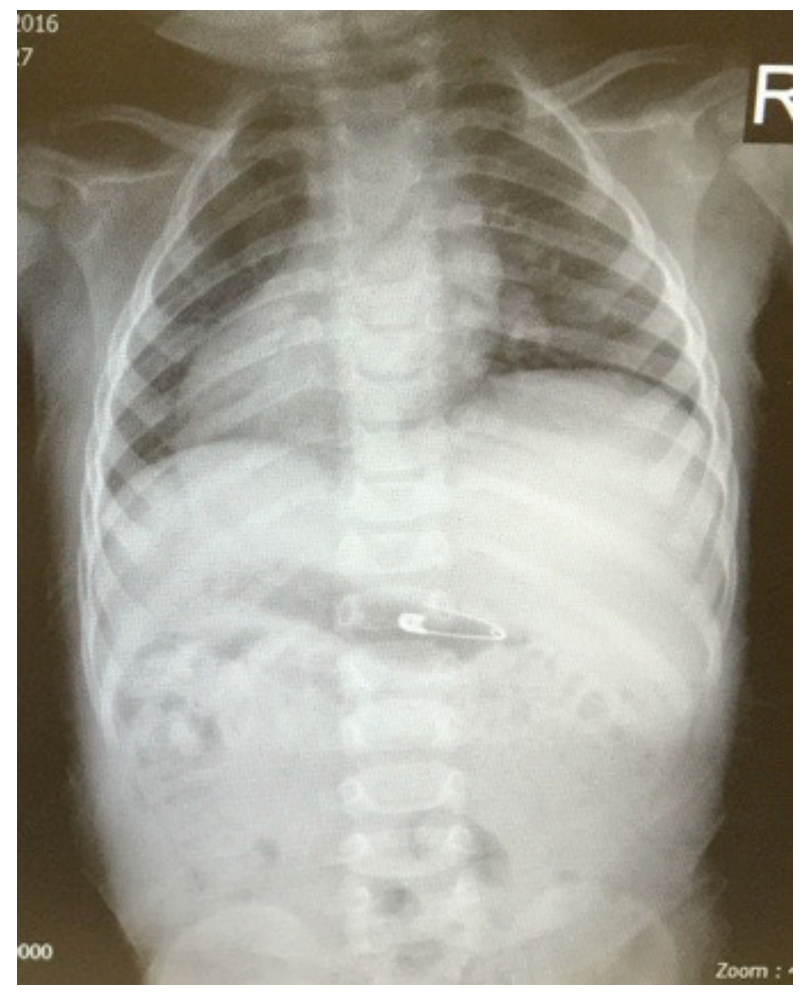

Figure 1: The open safety pin was seen in the first part of the duodenum

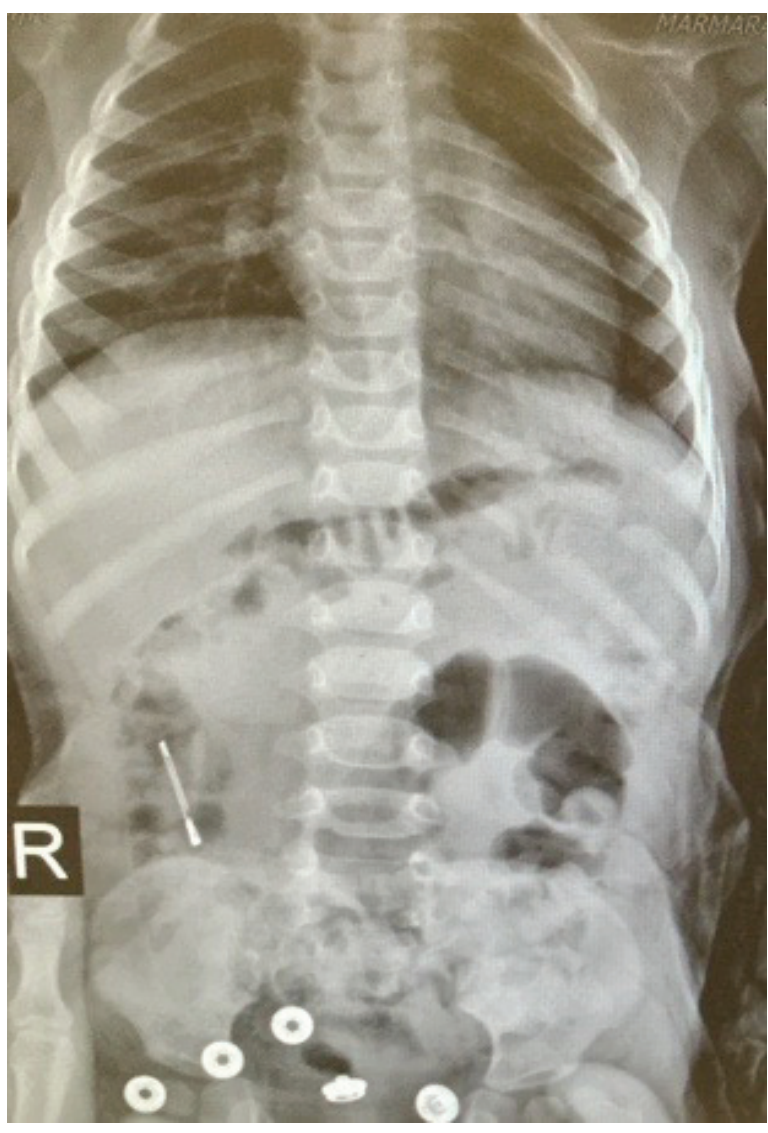

Figure 1: After twenty hours, the open safety pin was seen in the ascending colon 
watch his stool closely. In addition, the parents were warned about the symptoms of the complications. The day after, we called the family and learned that the open safety pin was spontaneously eliminated from stool.

\section{Discussion}

Sharp object ingestion is a common problem in the pediatric population, especially in the first three years $[18,19]$. Safety pin is a commonly ingested/aspirated material in Turkey due to cultural beliefs $[18,20]$. Aydogdu et al., reported 176 children with foreign body aspirations from Turkey, where the most commonly ingested objects were blue beads/safety pins, coins, and turban pins, $38.6 \%, 27.8 \%$, and $18.1 \%$, respectively [18]. Similar to our case, they reported blue beads/safety pins as being the main objects ingested by infants [18].

Although, many sharp objects may pass the gastrointestinal tract without complication [3,17], any child, with a clear history or a suspicion by family or caregivers, needs an urgent radiographic evaluation to decrease possible adverse complications because of delayed diagnosis and management [10]. If the sharp object is in the esophagus, it must be removed immediately due to the risk of perforation $[3,19]$. If it is in the stomach, removing it by endoscopy can also be considered [3]. Unless the patient is symptomatic, he or she can be followed clinically with serial x-rays [3]. Otherwise, it should especially be removed if symptoms develop or $>3$ days pass without passage [3]. In our case, since the open safety pin was in the first part of the duodenum and the patient was not symptomatic, we preferred to follow up the patient closely and took serial x-rays, which was a wait-and-observe attitude. The patient was followed closely, and we paid attention for the awareness of the family for probable complications. After 36 hours, the open safety pin was spontaneously eliminated from his stool without any intervention and complication.

In conclusion, infants and children with safety pin ingestion can be closely followed clinically without complication and there will be no need for any intervention like endoscopy and/or surgery. An open safety pin ingested small child was reported with the aim to draw attention to safety pin ingestion, which was eliminated spontaneously.

Acknowledgement: We are grateful to Hakan Şentürk (Editor of Writing Center in Yeditepe University) for his excellent revision of this paper in English.

\section{References}

1. 1- Bizakis JG, Prokopakis EP, Papadakis CE, Skoulakis CE, Velegrakis GA, Helidonis ES. The challenge of esophagoscopy in infants with open safety pin in the esophagus. Report of two cases. Am J Otolaryngol 2000;21:255-8.

2. 2-O'Brien GC, Winter DC, Kirwan WO, Redmond EP. Ingested foreign bodies in the paediatric patient. Ir J Med Sci 1999;170:100-2.

3. Kramer RE, Lerner DG, Lin T, Manfredi M, Shah M, Stephen TC, Gibbons TE, Pall H, Sahn B, McOmber M, Zacur G, Friedlander J, Quiros AJ, Fishman DS, Mamula P; North American Society for Pediatric Gastroenterology, Hepatology, and Nutrition Endoscopy Committee. Management of ingested foreign bodies in children: a clinical report of the NASPGHAN Endoscopy Committee. J Pediatr Gastroenterol Nutr 2015;60:562-74. doi: 10.1097/ MPG.0000000000000729.

4. Mehran A, Podkameni D, Rosenthal R, Szomstein S. Gastric perforation secondary to ingestion of a sharp foreign body. JSLS 2005;91-3.

5. Goh BK, Chow PKH, Quah, HM, et al. Perforation of the gastrointestinal tract secondary to ingestion of foreign bodies. World J Surg 2006;30:372-7. doi:10.1007/s00268005-0490-2

6. Paul R I, Jaffe DM. Sharp object ingestions in children: illustrative cases and literature review. Pediatr Emerg Care 1988;4:245-8.

7. Mirza B, Sheikh A. Open safety pin ingestion presenting as incarcerated umbilical hernia. APSP J Case Rep 2011;2:25.

8. McComas B C, van Miles P, Katz B E. Successful salvage of an 8-month-old child with an aortoesophageal fistula. J Pediatr Surg 1991;26:1394-5.

9. MacManus J E. Perforation of the intestine by ingested foreign bodies: report of two cases and review of the literature. Am J Surg 1941; 53:393-402.

10. Palta, R, Sahota A, Bemarki A, Salama P, Simpson N, laine 1. Foreign-body ingestion: characteristics and outcomes in a lower socioeconomic population with predominantly intentional ingestion. Gastrointest Endosc 2009;69:426-33. doi:10.1016/j.gie.2008.05.072

11. Sai Prasad TR, Low Y, Tan CE, et al. Swallowed foreign bodies in children: report of four unusual cases. Ann Acad Med Singapore 2006;35:49-53.

12. McComas BC, van Miles P, Katz BE. Successful salvage of an 8-monthold child with an aortoesophageal fistula. J Pediatr Surg 1991;26:1394-5.

13. Harjai MM, Gill M, Singh Y, Sharma A. Intra-abdominal needles: an enigma (a report of two cases). Int Surg 2000;85:130-2.

14. Sarıhan H, Kaklıkkaya I, Özcan F. Pediatric safety pin ingestion. J Cardiovasc Surg 1998;39:515-8.

15. Paul R I, Christoffel K K, Binns H J, Jaffe D M. Foreign body ingestions in children: risk of complication varies with site of initial health care contact. Pediatric Practice Research Group. Pediatrics 1993;91:121-7. 
16. Gregori D, Scarinzi C, Morra B, et al. and ESFBI study group. Ingested foreign bodies causing complications and requiring hospitalization in European children: results from the ESFBI study. Pediatr Int 2010;52:26-32. doi:10.1111/ j.1442-200X.2009.02862.x

17. Cheng W, Tam P K. Foreign-body ingestion in children: experience with 1,265 cases. J Pediatr Surg 1999;34: 1472-6.
18. Aydogdu S, Arıkan C, Çakır M, et al. Foreign body ingestion in Turkish children. Turk J Pediatr 2009;51:127-32.

19. Chen MK, Beierle EA. Gastrointestinal foreign bodies. Pediatr Ann 2001; 30: 736-42.

20. Chung S, Forte V, Campisi P. A rewiew of Pediatric Foreing Body İngestion and management. Clin Pediatr Emerg Med 2010; 1: 225-30. 